\title{
Mechanical Properties and Explosive Spalling Behavior of Steel-Fiber-Reinforced Concrete Exposed to High Temperature-A Review
}

\author{
Peng Zhang ${ }^{1}$, Luoyi Kang ${ }^{1}$, Juan Wang ${ }^{1, *}$, Jinjun Guo ${ }^{1}$, Shaowei $\mathrm{Hu}^{1,2}$ and Yifeng Ling ${ }^{3}$ (D) \\ 1 School of Water Conservancy Engineering, Zhengzhou University, Zhengzhou 450001, China; \\ zhangpeng@zzu.edu.cn (P.Z.); kanglyzzu@163.com (L.K.); guojinjun@zzu.edu.cn (J.G.); \\ hushaowei@cqu.edu.cn (S.H.) \\ 2 College of Civil Engineering, Chongqing University, Chongqing 400045, China \\ 3 Department of Civil, Construction and Environmental Engineering, Iowa State University, Ames, IA 50011, \\ USA; yling@iastate.edu \\ * Correspondence: wangjuan@zzu.edu.cn
}

Received: 9 March 2020; Accepted: 24 March 2020; Published: 28 March 2020

\begin{abstract}
Steel-fiber-reinforced concrete (SFRC) is being increasingly applied to various buildings and civil infrastructure as an advanced cementitious composite. In recent years, the requirements for SFRC in the construction industry have increased. Additionally, the fire resistance of SFRC has attracted attention; therefore, numerous investigations regarding the residual properties of SFRC have been conducted. This paper critically reviews the mechanical properties of SFRC subjected to elevated temperatures, including its residual compressive strength, flexural strength, tensile strength, elastic properties, fracture properties, and stress-strain relationships. The residual mechanical performance of SFRC and the action mechanism of steel fibers are reviewed in detail. Moreover, factors affecting the explosive spalling of concrete at high temperatures as well as the effect of steel fibers on the microstructure of heated concrete are discussed. It is demonstrated that, in general, SFRC exhibits better residual mechanical properties when exposed to elevated temperatures than plain concrete and can prevent the risk of explosive spalling more effectively. The purpose of this literature review is to provide an exhaustive insight into the feasibility of SFRC as a refractory building material; additionally, future research needs are identified.
\end{abstract}

Keywords: steel-fiber-reinforced concrete; high temperature; mechanical property; explosive spalling behavior; microscope property

\section{Introduction}

Concrete is a traditional man-made building material. Although its tensile strength or brittleness is low [1-4], it is the most used material in the construction industry owing to its wide material availability, well workability, high strength, and low cost. Currently, with the continuous development of the construction and infrastructure industries, high-rise buildings and underground structures are increasing at an alarming rate. However, these structures are more susceptible to fire owing to the widespread use of gas and electrical appliances as well as the complexity of building functions. Fire hazards are the more serious issue. In recent years, fires occurring in these structures have been frequently reported worldwide, which have seriously threatened the safety of people and properties. Therefore, the residual performance of concrete exposed to elevated temperatures or the mechanical properties of concrete under elevated temperatures have attracted increasing attention and discussion from researchers $[5,6]$. It has been discovered that concrete subjected to high temperatures or fire exhibit physical and chemical reactions, such as dehydration and decomposition, which will not only 
severely damage the microstructure of concrete but also reduce the strength and stiffness of concrete, thereby causing the explosive spalling and mechanical decay of concrete [7-10]. Numerous previous studies have shown that the accumulation of pore vapor pressure inside concrete and thermal stresses are the main factors affecting the strength deterioration mechanism and the occurrence of explosive spalling, which significantly degrades the mechanical properties of concrete during fires [11-18]. Hence, concrete can be reinforced by incorporating fibers.

It has been well established that adding randomly distributed steel fibers into concrete can significantly improve its compressive strength, tensile strength, ductility, and impact resistance at room temperature [19-22]. Furthermore, steel-fiber-reinforced concrete (SFRC) can be used as a primary building material in various constructions and infrastructures, for instance, ground-supported slabs, road paving, and tunnel linings, because of its outstanding performance in improving the tensile strength of concrete and its ability in controlling crack propagation [22-24]. Therefore, the effect of steel fibers on the residual mechanical properties of concrete after elevated temperature exposure and the effect of explosive spalling of concrete during fires or at high temperatures have become popular topics in recent years. Furthermore, many investigations have been conducted to examine the residual properties and explosive spalling behavior of SFRC [25-27]. When concrete is exposed to fires or high temperatures, the existence of steel fibers can reduce the water vapor pressure in the pores of concrete and bridge cracks inside concrete, as well as reduce the temperature gradient by allowing more heat into the concrete to decrease the possibility of explosive spalling and concrete cracking at high temperatures, which contribute positively to the fire resistance of concrete [28-32]. Meanwhile, the residual mechanical properties of concrete in a post-fire environment can be improved significantly [31-33]. However, the applicability of SFRC when exposed to high-temperature environments is hampered by international regulatory inconsistencies. Therefore, a review of previous studies regarding the residual mechanical properties and explosive spalling behavior of SFRC within a certain temperature increase range is crucial to obtain the basic data of application feasibility.

One of the important foundations for accurately evaluating the usability of construction after a fire is research on the residual mechanical properties of concrete. Furthermore, the compressive strength, flexural strength, tensile strength, elastic modulus, fracture energy, and stress-strain relationship of concrete are important mechanical properties that are often used for evaluating the fire resistance of concrete structures. Numerous literatures have comprehensively reported the residual mechanical properties of steel-fiber-reinforced concrete. In most of these studies, residual unstressed tests were performed, in which samples were naturally cooled to room temperature and then continuously loaded until it was destroyed [34,35]. There are a lot of types of steel fiber that can be used in concrete. Based on the fiber shape, steel fibers can be classified as milling steel fiber, hooked-end steel fiber, straight steel fiber, corrugated steel fiber, dumbbell steel fiber, sheet and hooked-side steel fiber, needle twisted steel fiber, and so on. Among these different types of steel fiber, the first four types are often used in concrete. The common used length varies from 20 to $40 \mathrm{~mm}$, and the aspect ratio often varies from 40 to 80 . The elastic modulus and tensile strength are usually determined as about $200 \mathrm{GPa}$ and 800-1300 MPa. In this context, this review reports recent advances pertaining to the effects of a high temperature on the residual mechanical properties, explosive spalling behavior, and microstructure of SFRC. This review is classified into four parts. A detailed description of the effect of steel fiber on the residual mechanical properties of concrete is provided. The first part summarizes the available experimental data of residual mechanical properties of concrete subjected to an elevated temperature; additionally, the residual mechanical properties of SFRC including compressive strength, flexural strength, tensile strength, elastic properties, fracture properties, and stress-strain relationships are discussed. In the second part, the main influencing factors of the explosive spalling behavior of concrete and the mechanism of explosive spalling are introduced comprehensively and, on this basis, the effect mechanism of steel fiber for preventing the explosive spalling behavior of concrete subjected to high temperatures is discussed in detail. The third part discusses the microstructure of SFRC after it 
is subjected to a high temperature. Finally, based on the collected data and analysis, conclusions and future perspectives are provided.

\section{Mechanical Properties of SFRC Exposed to High Temperature}

\subsection{Residual Compressive Strength}

The residual compressive properties of concrete exposed to elevated temperatures are particularly important not only for the fire protection design of the structure, but also for the evaluation and repair of the structure. A considerable number of experimental studies regarding the residual compressive strength of SFRC have been conducted. Some experimental data regarding the residual compressive strength of SFRC are presented in Figure 1. As shown, the relationship between the maximum exposure temperature and the residual compressive strength can be classified into three different stages:(1) In the primary stage, the residual compressive strength of SFRC decreased slightly and may even increase slightly as the high temperature caused the cement hydration reaction to occur more fully when the temperature range was between the room temperature and $400^{\circ} \mathrm{C}$. (2) In the second stage, the residual compressive strength of SFRC decreased significantly as the temperature increased from 400 to $800{ }^{\circ} \mathrm{C}$. (3) In the final stage, the residual compressive strength of SFRC was almost completely lost when the temperature was beyond $800{ }^{\circ} \mathrm{C}$.

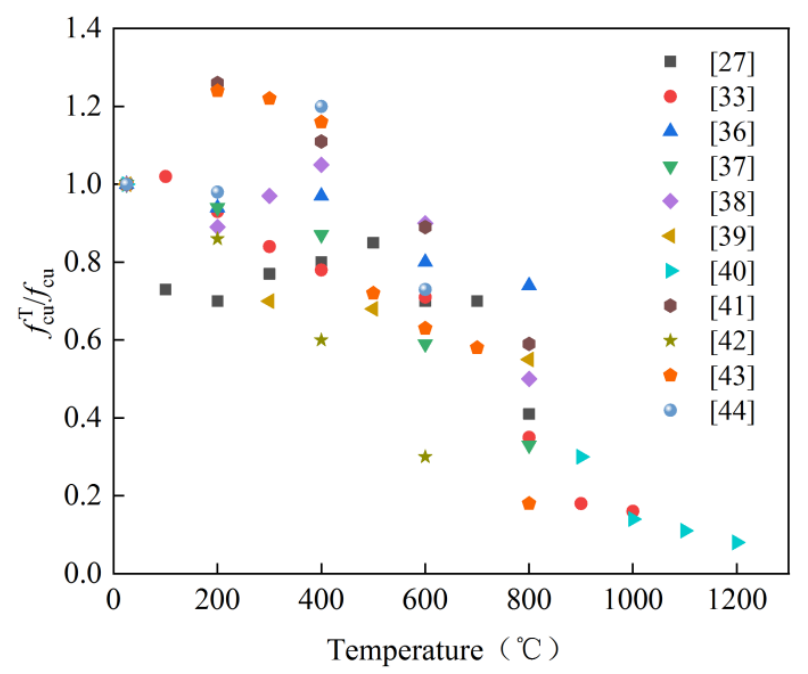

Figure 1. Relative compressive strength of steel-fiber-reinforced concrete (SFRC) after exposure to elevated temperatures $[27,33,36-44]$.

As shown in the comparative test data, the attenuation of the residual compressive strength of concrete is effectively suppressed because of the utilization of steel fibers. Lau and Anson [33] observed that in the temperature range of $105-1200{ }^{\circ} \mathrm{C}$, the residual compressive strength of concrete could increase by $5 \%-15 \%$ by adding steel fibers with a volume content of $1 \%$. Xie et al. [37] compared specimens with $1 \%$ volumetric quantity of steel fibers with specimens without steel fiber and discovered that the compressive strength of the former improved by $19.4 \%$ at $200{ }^{\circ} \mathrm{C}, 24.3 \%$ at $400{ }^{\circ} \mathrm{C}, 92.9 \%$ at $600{ }^{\circ} \mathrm{C}$, and $123.2 \%$ at $800{ }^{\circ} \mathrm{C}$. The residual compressive strength of $28 \mathrm{~d}$ samples with $1.0 \%$ steel fiber additive was $48 \%$ higher than that of the sample without a steel fiber additive, when the maximum exposure temperatures were $900{ }^{\circ} \mathrm{C}$ and $1000{ }^{\circ} \mathrm{C}$ [40]. Ismail et al. [36] described that the compressive strength of concrete reinforced with $0.5 \%$ steel fiber was higher than that of the control concrete when the temperature was increased from 20 to $800^{\circ} \mathrm{C}$. As the concrete was exposed to high temperatures, the $\mathrm{C}-\mathrm{S}-\mathrm{H}$ in the matrix became hydrated and dehydrated, and thermal disconformity occurred inside the cement when the aggregate was heated; furthermore, the pore pressure generated by water accumulated in the pores of cement was a crucial factor for the volume expansion of the concrete [33,45]. 
With these expansions and shrinkages occurring inside the concrete, cracks began to appear and develop gradually, which caused the compressive strength of the concrete to decline [40,46]. Owing to the bridging crack effect of the steel fibers, after the steel fibers were applied to the concrete, the volume change behavior of the concrete under a rapid temperature change or high temperature environment was limited, and the initiation and expansion of the defects that occurred inside the concrete reduced $[37,38,47]$. Meanwhile, its inherently high melting temperature guaranteed its good performance under high-temperature conditions. Therefore, the deterioration of the residual compressive strength of concrete can be reduced using steel fibers.

The residual compressive strength of concrete is affected by the volume content of steel fibers. Chen et al. [39] observed the variation law of residual compressive strength of samples prepared with different steel fiber contents $\left(0,40,80,120\right.$, and $\left.160 \mathrm{~kg} / \mathrm{m}^{3}\right)$ at different maximum temperatures through experiments. As illustrated in Figure 2, with the increase in steel fiber dosage, the residual compressive strength of SFRC increased between the room temperature and $300^{\circ} \mathrm{C}$. However, from 500 to $800{ }^{\circ} \mathrm{C}$, when the steel fiber content was less than $80 \mathrm{~kg} / \mathrm{m}^{3}$, the compressive strength of SFRC increased with the steel fiber content; furthermore, when the steel fiber dosage continued increasing to $160 \mathrm{~kg} / \mathrm{m}^{3}$, the compressive strength of SFRC decreased with the increase in steel fiber dosage. This changing trend is supported by the conclusion of Zheng et al. [27,48]. When the concrete was exposed to a temperature beyond $900{ }^{\circ} \mathrm{C}$, the variation trend of the residual compressive strength of SFRC as shown in Figure 3 , showing that when the steel fiber content is less than $1 \%$, the residual compressive strength of SFRC increases with the steel fiber content; however, when the steel fiber content surpasses $1 \%$, the residual compressive strength decreases with the increase in steel fiber dosage, and the age of concrete exerted little effect on this trend [40]. When the temperature increased beyond $500{ }^{\circ} \mathrm{C}$, the effect of the steel fibers began to become more significant; however, a higher steel fiber content caused coagulation in the steel fibers, resulting in reduced usable area. Moreover, a greater thermal expansion between the cement and steel fiber generated more cracks, which was considered to be the reason for the decrease in the compressive strength of concrete with the increase in steel fiber dosage [27,40]. In addition, Scheinherrová et al. [49] discovered that the residual compressive behavior of concrete exposed to high temperatures was affected by the type of steel fiber coating. Under high temperatures, the compressive strength of reactive powder concrete with $\mathrm{Cu}-\mathrm{Zn}$-coated steel fibers was significantly higher than that reported in [43].

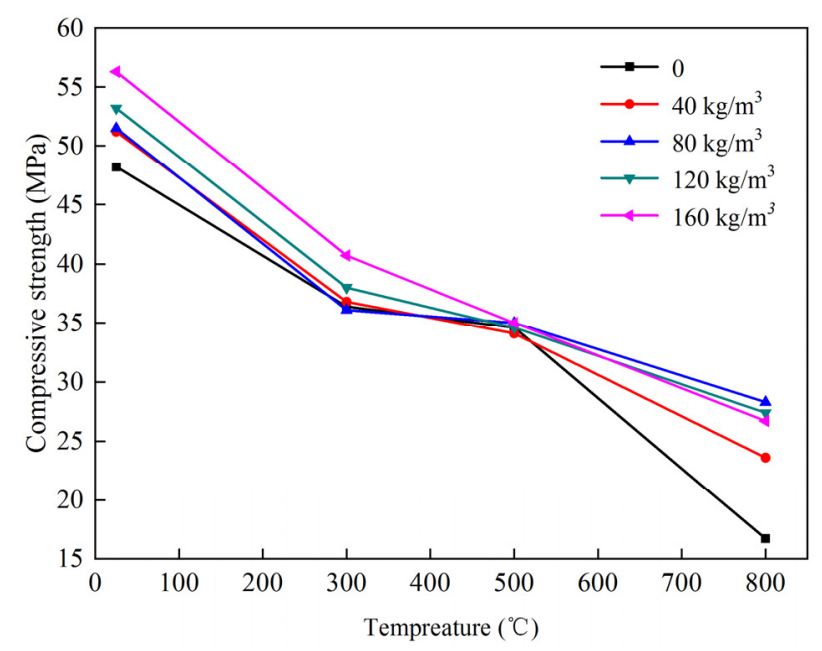

Figure 2. Residual compressive strength of SFRC as a function of temperature [39]. 


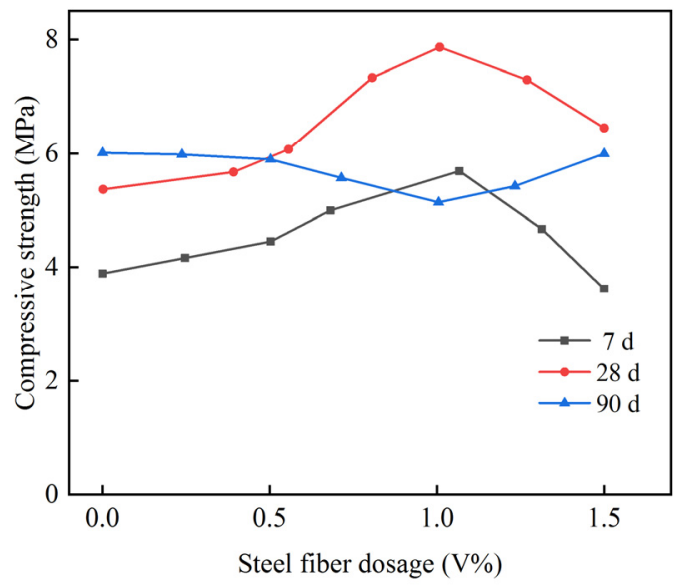

(a) Exposure to $900^{\circ} \mathrm{C}$

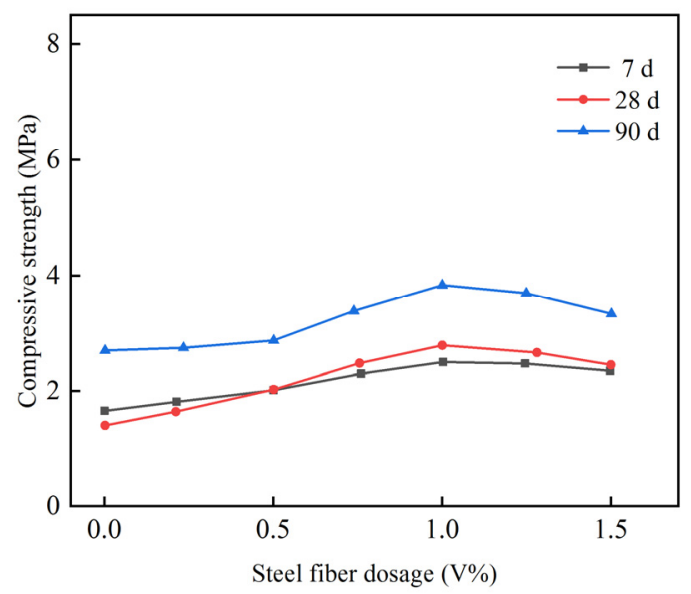

(c) Exposure to $1100{ }^{\circ} \mathrm{C}$

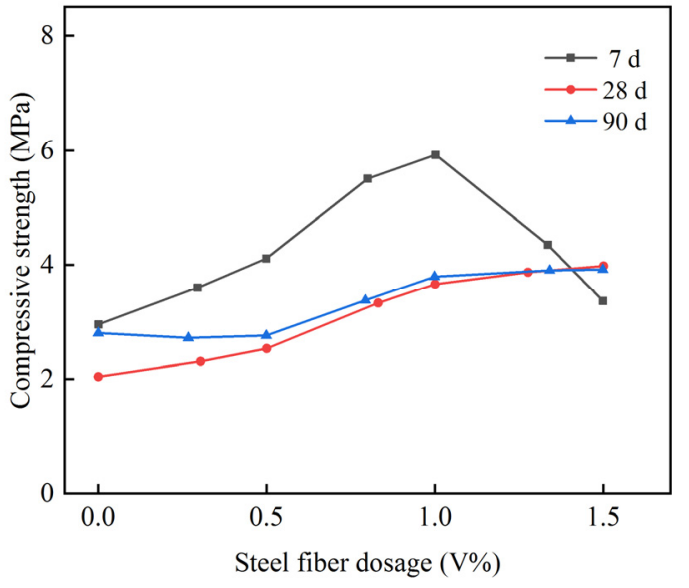

(b) Exposure to $1000^{\circ} \mathrm{C}$

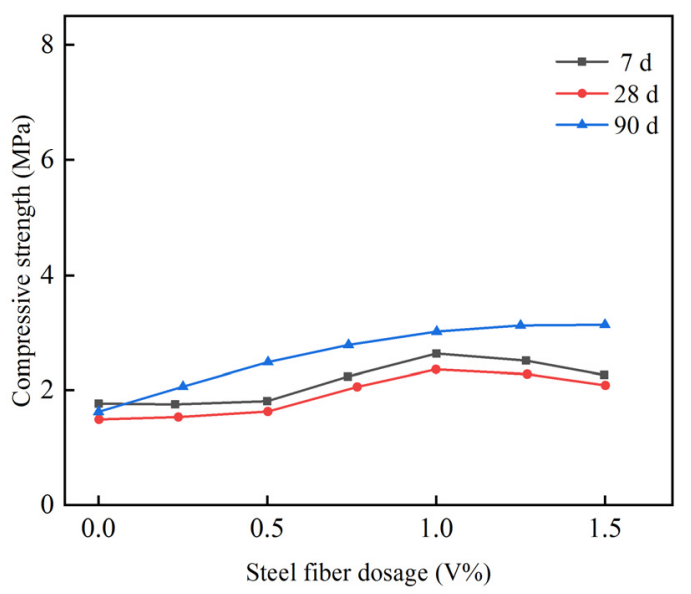

(d) Exposure to $1200{ }^{\circ} \mathrm{C}$

Figure 3. Relationship between compressive strength of SFRC and steel fiber dosage [40].

The initial saturation percentages of the sample and its temperature history, such as the heating rate and cooling regime, may be the main parameters used to determine the effect of steel fiber actions. After being exposed to heating at different high temperatures, the residual compressive strengths of concrete reinforced with $1 \%$ steel fiber of water curing with three different water saturation percentages $(20 \%, 60 \%$, and $100 \%)$ were investigated by Lau and Anson [31]. They discovered that increased saturation percentages reduced the strength of SFRC, regardless of the maximum heating temperature, which ranged from 105 to $1200{ }^{\circ} \mathrm{C}$. This may be because SFRC with high saturation percentages in the heating process resulted in a greater pore pressure, and hence more internal defects. The existence of steel fibers can reduce the pore pressure more effectively under relatively high pressures in deep areas of concrete during a relatively fast heating process rather than at a slow heating rate $\left(5^{\circ} \mathrm{C} / \mathrm{min}\right)[50]$, which results in a higher retention of the original mechanical properties of SFRC. It has been reported that the residual compressive strength of SFRC decreases more than that of naturally cooled concrete owing to severe thermal shock after water-cooling treatments [51-53]. This may be due to the different thermal expansion characteristics between the concrete matrix and steel fibers, in which water cooling caused more severe interface mismatches between the concrete matrix and steel fiber [54]. In addition, the mechanical properties of steel fibers may be altered [55]. 


\subsection{Residual Flexural Properties}

Studies regarding the residual flexural properties of SFRC are limited. The flexural testing of SFRC has been performed on prisms, but the specimen sizes used previously varied because of the lack of standardized test specifications, including $150 \mathrm{~mm} \times 150 \mathrm{~mm} \times 550 \mathrm{~mm}$ [56], $150 \mathrm{~mm} \times 150$ $\mathrm{mm} \times 600 \mathrm{~mm}$ [25], $100 \mathrm{~mm} \times 100 \mathrm{~mm} \times 400 \mathrm{~mm}$ [33], and $100 \mathrm{~mm} \times 100 \mathrm{~mm} \times 500 \mathrm{~mm}$ [57]. Lau and Anson [33] concluded that the flexural properties of concrete reinforced with $1 \%$ steel fiber were better than those of concrete without steel fiber when the maximum exposure temperature ranged from 105 to $800{ }^{\circ} \mathrm{C}$. However, non-fiber mixtures and SFRC differed in terms of residual flexural strength when the mixtures were exposed to temperatures beyond $800^{\circ} \mathrm{C}$. This may be due to the steel fibers, which provided a considerable degree of ductility when concrete was heated below $800^{\circ} \mathrm{C}$. However, as the temperature increased further, the mechanical properties of the steel fibers appeared to be degraded owing to oxidation and corrosion [58,59], resulting in insufficient ductility. The residual flexural strength of different fiber-reinforced concrete (FRC) has been proposed by Jameran et al. [56].In their study, a concrete mixture was reinforced by hybrid fibers with a volume content of $1.5 \%$, in which the percentages of steel and propylene fiber were $100 \%$ and $0 \%, 75 \%$ and $25 \%, 50 \%$ and $50 \%, 25 \%$ and $75 \%$, and $0 \%$ and $100 \%$. The data results are shown in Figure 4 . It is evident from Figure 4 that the single steel-fiber-reinforced concrete has a higher residual flexural strength than the hybrid steel and polypropylene fiber FRCs and single polypropylene FRC when the specimens were exposed to high temperatures of $200{ }^{\circ} \mathrm{C}$ and $400{ }^{\circ} \mathrm{C}$. This is similar to the results of Pliya et al. [60] and Choumanidis et al. [57], in which the heating temperatures were $300^{\circ} \mathrm{C}$ and $280^{\circ} \mathrm{C}$, respectively.

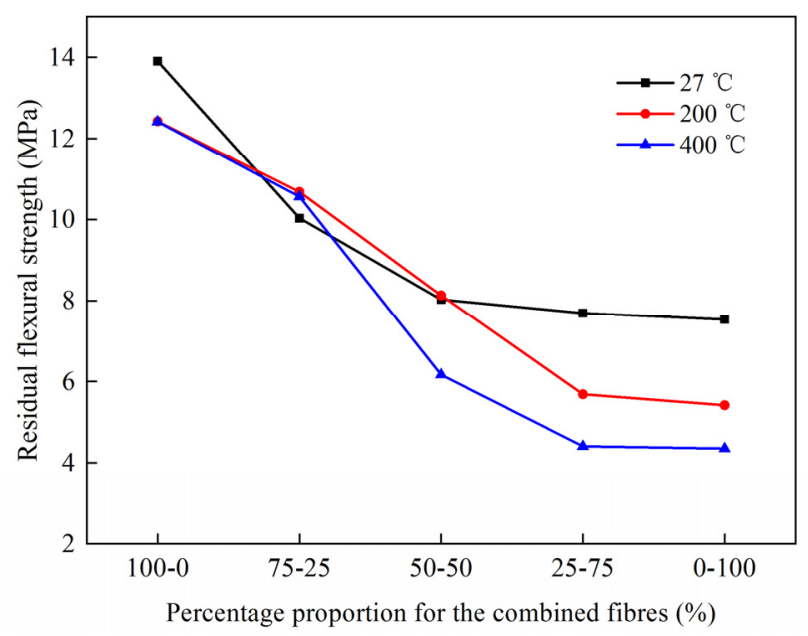

Figure 4. Residual flexural strength of fiber-reinforced concrete (FRC) [56].

\subsection{Residual Tensile Strength}

The tensile strength of concrete is often disregarded in the calculation of strength, because the tensile strength of concrete is significantly lower than the compressive strength [61]. Furthermore, a higher temperature would result in a more significant reduction in the tensile strength of concrete than the compressive strength. This may be because the tensile strength is more susceptible to microcracks in the interface transition zone caused by elevated temperatures compared with the compressive strength $[62,63]$. Its importance is crucial when concrete is heated because the tensile properties can inhibit crack expansion inside concrete [64]. In addition, the tensile properties of concrete can resist the internal vapor pressure generated by high temperatures to prevent explosive spalling in concrete [65]. Hence, to improve the tensile strength of concrete after exposure to high temperatures by preventing and minimizing the explosive spalling caused by fires, it is critical to add steel fibers to concrete. A large number of studies $[27,28,56,63,66-68]$ have demonstrated that steel fibers contributed positively to improving the residual tensile strength of concrete. This may be because steel fibers can maintain 
their mechanical properties at high temperatures; therefore, they could still bridge cracks under tensile loading and improve the microstructure of heated concrete owing to the limited expansion of defects in the concrete interior [58]. In addition, adding steel fibers could improve the thermal conductivity of concrete owing to the higher thermal conductivity of steel fiber than those of cement matrix and aggregates; therefore, SFRC exhibited a more uniform internal thermal stress after heating, thereby reducing the internal damage caused by thermal gradients in concrete $[37,68,69]$. Ultimately, the residual tensile strength of steel-fiber-reinforced concrete subjected to high temperatures would be improved.

It has been discovered that the dosage, geometry type, and aspect ratio of steel fibers are main factors affecting the residual tensile strength of SFRC. According to the study of Gao et al. [28], as the content of steel fiber increased from $0 \%$ to $2 \%$, the residual splitting tensile strength of ground granulated blast furnace slag concrete after being exposed to $400{ }^{\circ} \mathrm{C}$ increased correspondingly. However, in terms of the relative tensile strength, $1.0 \%$ steel fiber was the optimal amount of concrete. Zheng et al. [27] studied the relation between the relative tensile strength of reactive powder concrete and steel fiber content and discovered that the relative tensile strength increased as the steel fiber content increased from $1 \%$ to $3 \%$ when the temperature was below $600{ }^{\circ} \mathrm{C}$; however, the relative tensile strength decreased at temperatures from 600 to $800^{\circ} \mathrm{C}$ with an increase in steel fiber dosage. Kim et al. [63] investigated the effects of steel fibers of different aspect ratios $(1 / \mathrm{d}=60$ or 80$)$, geometry types (twisted or hooked), and volume content $(0 \%, 0.25 \%, 0.5 \%$, or $1 \%)$ on the residual tensile strength of specimens using double-impact tests when the specimens were exposed to $15^{\circ} \mathrm{C}, 300{ }^{\circ} \mathrm{C}, 500^{\circ} \mathrm{C}$, and $700^{\circ} \mathrm{C}$. Figure 5 shows the effects of steel fiber types, the aspect ratio, and content on the residual tensile strength of concrete. As shown, the dosage and aspect ratio of steel fiber exerted a greater impact on the residual tensile strength of SFRC compared with its geometric type. At all test temperatures, the residual tensile strength of SFRC increased with the amount of steel fiber, regardless of its type and the aspect ratio. The residual tensile strength of SFRC was barely affected by the geometrical type of steel fiber, whereas the higher aspect ratio of steel fiber exerted a better effect on the tensile strength of SFRC.

\subsection{Residual Elastic Properties}

In fires or high-temperature environments, the excessive deformation of a structure will not only cause bearing capacity loss, but also structure damage. Elastic properties are important indicators of the ability of concrete to deform. Elastic modulus and Young's modulus are the indexes that are typically used for evaluating the elastic properties of concrete. In particular, Guo et al. [70] reported that high temperatures exerted the most significant effect on the elastic modulus of all the mechanical properties of concrete. Therefore, various experimental studies regarding the residual elastic properties of SFRC after heating have been performed. According to the findings of Lau and Anson [33], after being exposed between 105 and $1100{ }^{\circ} \mathrm{C}$, the loss of elastic modulus of a control concrete increased from $7 \%$ to $93 \%$, whereas that of concrete reinforced with $1 \%$ steel fiber ranged from $14 \%$ to $94 \%$; both decreased approximately linearly. Steel fibers can improve the residual elastic modulus of concrete when the maximum heating temperature is below $800^{\circ} \mathrm{C}$; however, above $800^{\circ} \mathrm{C}$, the elastic modulus of concrete and SFRC are almost similar. Düg enci et al. [40] calculated the tangent and secant modulus of elasticity of SFRC specimens subjected to $900^{\circ} \mathrm{C}, 1000^{\circ} \mathrm{C}, 1100^{\circ} \mathrm{C}$, and $1200^{\circ} \mathrm{C}$. The results indicated that the tangent and secant modulus of elasticity of concrete were parallel to the change in compressive strength but insensitive to the change in steel fiber content at the test temperatures. The results of Tai et al. [43] indicated that the elastic modulus of reactive powder concrete reinforced by different steel fiber contents $(1 \%, 2 \%$, and $3 \%)$ decreased rapidly with increasing temperature, but the rate of decline slowed at temperatures exceeding $600{ }^{\circ} \mathrm{C}$. Furthermore, a higher steel fiber content implied that reactive powder concrete (RPC) exhibited a higher elastic modulus above $400^{\circ} \mathrm{C}$. Furthermore, the data showed that the residual elastic modulus observed in SFRC was higher than that in plain concrete; this may be because the addition of steel fibers increased the cohesion of the matrix, thereby providing the 
necessary bond for preventing crack development and improving the ductility of concrete. However, their effects were impeded by their being oxidized and softened above $800^{\circ} \mathrm{C}[43,71]$.

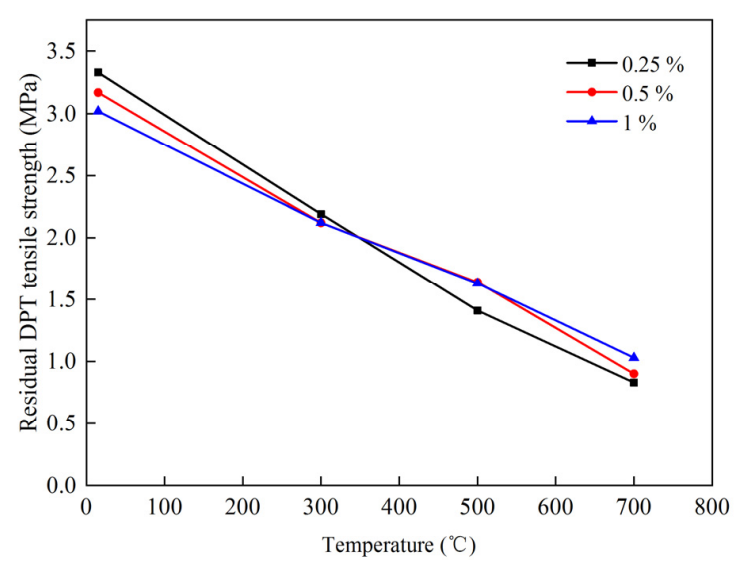

(a) SFRC with hooked fibers $(1 / d=60)$.

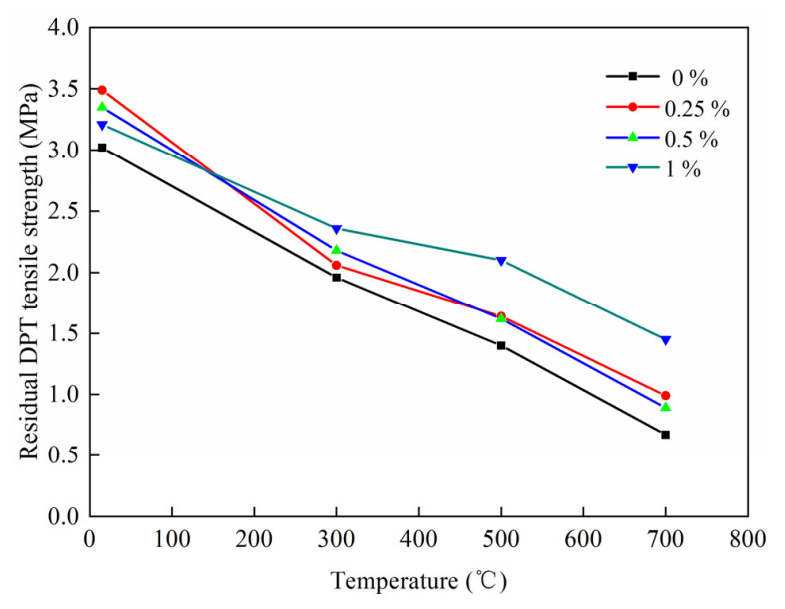

(b) SFRC with hooked fibers $(\mathrm{l} / \mathrm{d}=80)$.

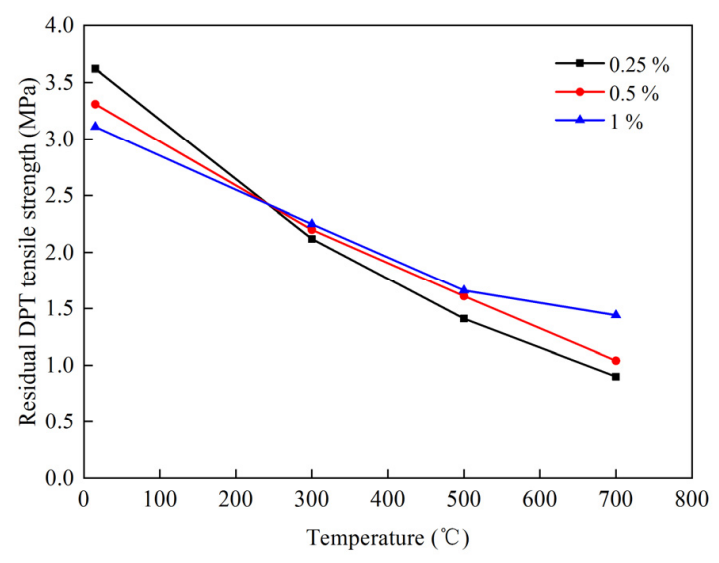

(c) SFRC with twisted fibers $(1 / \mathrm{d}=80)$.

Figure 5. Relationship between temperature and residual tensile strength of the three specimens [63].

The presence of steel fibers can enhance the residual elastic modulus of recycled aggregate concrete (RAC). The effects of steel fiber on the elastic properties of RAC are controversial when RAC is exposed to $25^{\circ} \mathrm{C}$ or $200^{\circ} \mathrm{C}$. Xie et al. [37] reported that the elastic modulus of $1 \%$-steel-fiber-reinforced RAC increased by $3.7 \%$ at $25{ }^{\circ} \mathrm{C}$ and $2.7 \%$ at $200{ }^{\circ} \mathrm{C}$ compared with RAC without steel fibers. However, the findings of Chen et al. [13,42] indicated that the elastic properties of steel-fiber-reinforced RAC was not comparable to those of RAC, and the Young's modulus of the samples decreased with the dosage of steel fiber increased from $0.5 \%$ to $1.5 \%$ when the samples were exposed to $25^{\circ} \mathrm{C}$ and 200 ${ }^{\circ} \mathrm{C}$. However, both results indicated that the addition of steel fibers enhanced the elastic properties of RAC when the exposure temperature exceeded $200{ }^{\circ} \mathrm{C}$. In addition, Xie et al. [37] showed that the low content of silica fume (substitution ratio of $4 \%$ ) was beneficial for improving the elastic modulus of steel-fiber-reinforced RAC exposed to above $400{ }^{\circ} \mathrm{C}$.

\subsection{Residual Fracture Properties}

Fracture properties are often used to evaluate the safety and toughness of concrete structures, as they are an important basis for the fracture analysis of concrete materials. Studying the residual fracture properties of concrete is critical for the identification and reinforcement of concrete buildings after fires. Furthermore, the residual fracture properties of concrete must be enhanced to prevent 
structure fractures. The three-point bending test is a typical test method to study the fracture behavior of concrete. Fracture toughness and fracture energy are important parameters that are widely used to quantify the fracture properties of concrete. When the temperature is increasing from 25 to 400 ${ }^{\circ} \mathrm{C}$, the fracture energy of concrete increases gradually [72-74]. The main reason for consuming more energy is that thermal damage causes cracks to develop in a tortuous process, rather than the sharp process observed at room temperature [72,73]. Hence, the addition of steel fibers will further increase the fracture energy. The results of Chen et al. [13] indicated that the residual fracture toughness and fracture energy of RAC after exposure to $25^{\circ} \mathrm{C}, 200{ }^{\circ} \mathrm{C}, 400{ }^{\circ} \mathrm{C}$, and $600{ }^{\circ} \mathrm{C}$ improved significantly after the addition of steel fiber. The effects of exposure temperature and steel fiber content on fracture energy and fracture toughness are shown in Figures 6-8. Moreover, the enhancement of the unstable fracture toughness from the addition of steel fibers was greater than that of the initiation fracture toughness, and the former was approximately twice that of the latter. Watanabe et al. [75] analyzed the fracture energy of different fiber-reinforced high-strength concrete in hot and residual tests, at temperatures ranging from 20 to $600{ }^{\circ} \mathrm{C}$. The experimental results indicated that the fracture energy of plain concrete and polypropylene-fiber-reinforced concrete was similar, but the fracture energy of hybrid steel and polypropylene-fiber-reinforced concrete was higher than those of plain concrete and polypropylene-fiber-reinforced concrete. The main mechanisms for amelioration in the fracture properties of concrete is as follows: steel fibers can bridge the microcracks inside concrete and restrict the development of cracks, and steel fibers can decelerate the volume change caused by the temperature gradient of concrete by increasing the heat transfer coefficient of concrete [13,33,75-77].

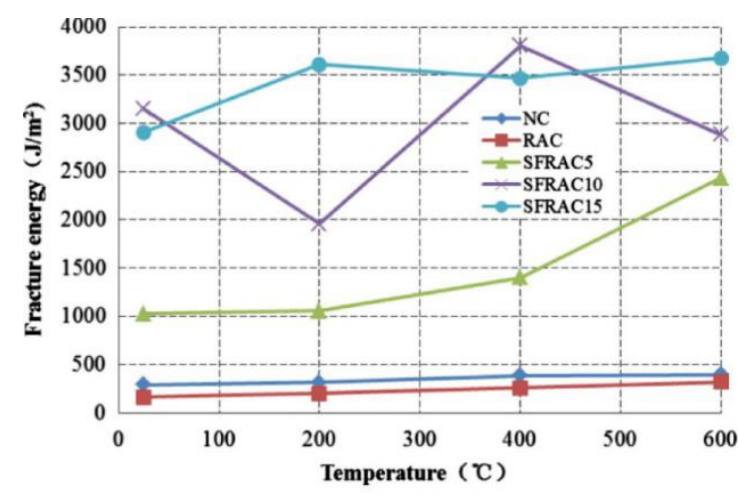

(a) Effect of exposure temperature.

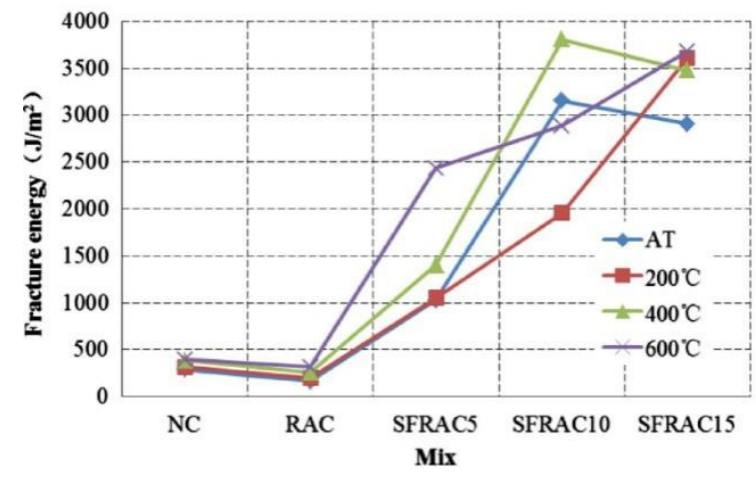

(b) Effect of steel fiber content.

Figure 6. Effects of exposure temperature and steel fiber content on fracture energy [13].

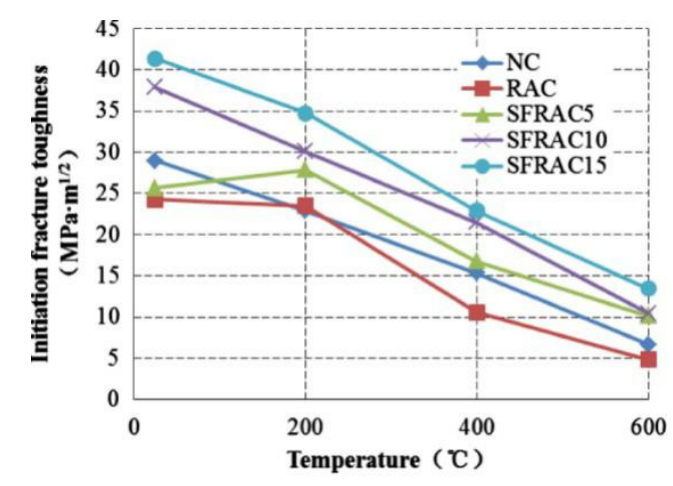

(a) Effect of exposure temperature.

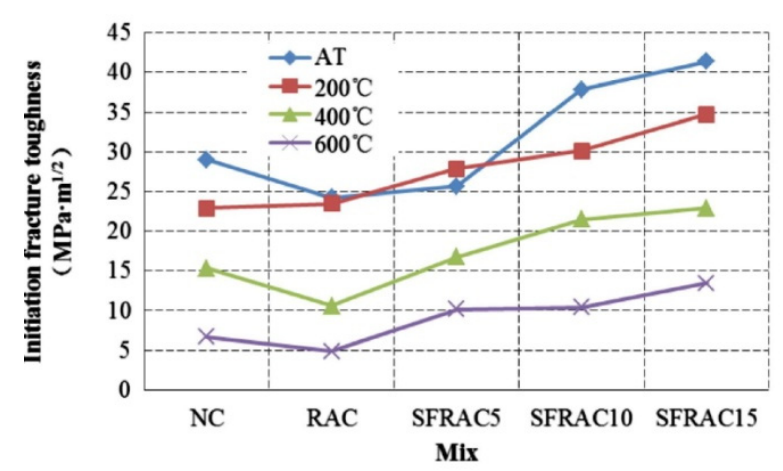

(b) Effect of steel fiber content.

Figure 7. Effects of exposure temperature and steel fiber content on initiation fracture toughness [13]. 


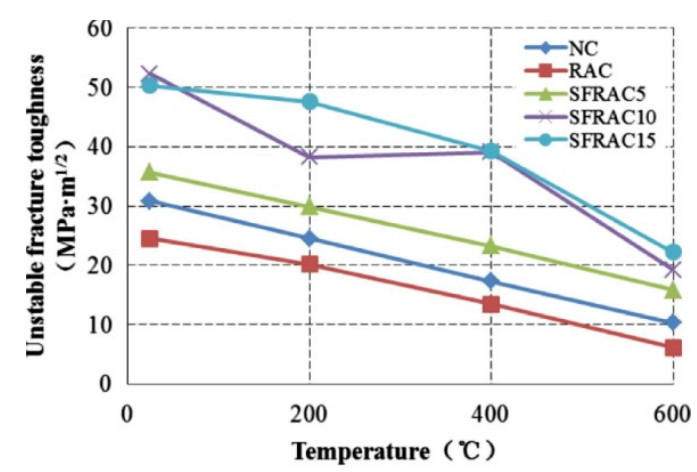

(a) Effect of exposure temperature.

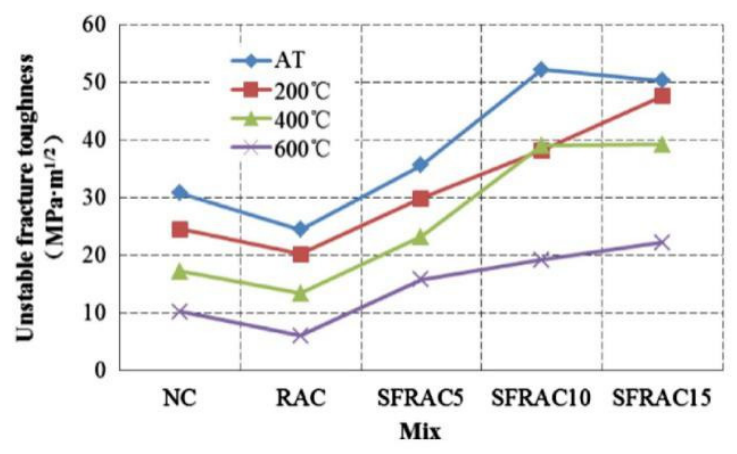

(b) Effect of steel fiber content.

Figure 8. Effects of exposure temperature and steel fiber content on unstable fracture toughness [13].

\subsection{Stress-Strain Relationship}

The mechanical response of concrete is typically expressed by the stress-strain relationship, which is important for determining concrete performance in the design process of the concrete structure. To reasonably assess the fire resistance of SFRC structures, the stress-strain relationship of SFRC after being subjected to high temperatures has been studied. It has been reported $[36,37,42,44,70,78,79]$ that with the increase in temperature, the slopes of the stress-strain curves of SFRC tended to be gentle in both the pre-peak and post-peak stages, the peak stress moved downward and rightward, and the curves became flatter. The stress-strain curves of concrete reinforced by different steel fiber contents $(0 \%, 1 \%$, and $2 \%)$ after exposure to different temperatures are shown in Figure 9 . It is clear that the peak stress decreases as the temperature increases gradually, whereas the strain at the peak stress increases with temperature. Poon et al. [36] and Chen et al. [42] reported that the shape of the stress-strain curve of SFRC beyond elevated temperatures changed significantly owing to the presence of steel fibers. Under the same heat treatment conditions, the stress-strain curves of SFRC exhibit a more flattened descending branch and a larger area that is surrounded by the stress-strain curve and coordinate axis, compared with plain concrete. Zheng et al. [78] discovered that the area under the stress-strain curve increased gradually with the dosage of steel fiber. The energy absorption capacity (toughness) of concrete is defined as the area under the stress-strain curve calculated to a specified strain value, which is the maximum strain value in the stress-strain curve $[80,81]$. The addition of steel fiber improved the toughness of heated concrete significantly.
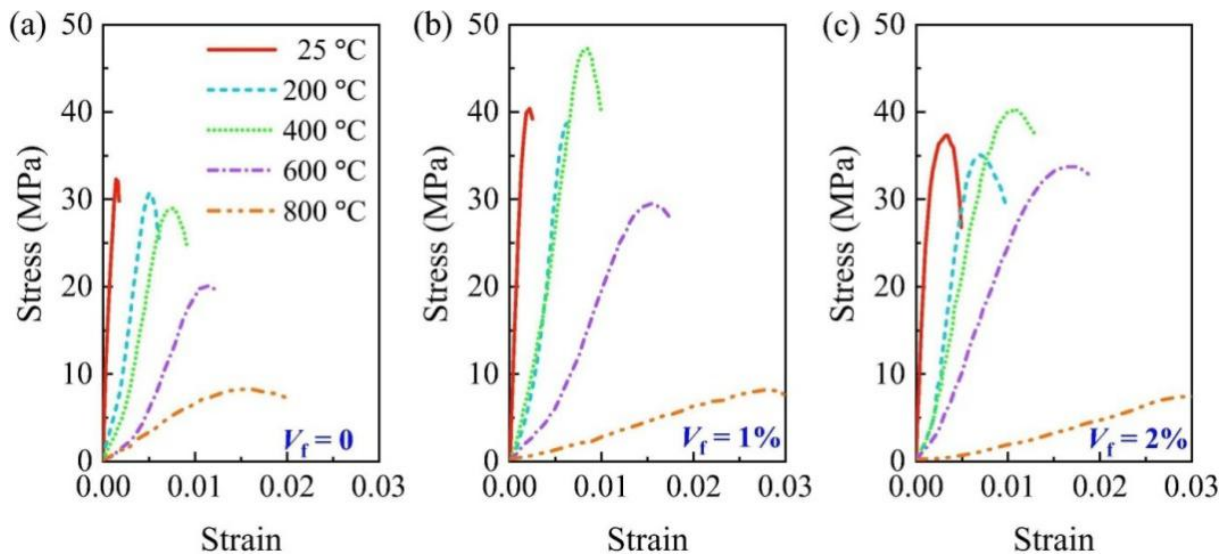

Figure 9. Stress-strain curves of SFRC exposed to different temperatures with steel fiber dosage of $0 \%$ (a), $1 \%($ b) and $2 \%$ (c) [44]. 
In this part, the residual mechanical properties of SFRC exposed toa high temperature were described, and a detailed description of the effect of steel fiber on the compressive strength, flexural strength, tensile strength, elastic properties, fracture properties, and stress-strain relationships of heated concrete was provided. When the maximum exposure temperature was less than $800{ }^{\circ} \mathrm{C}$, the residual mechanical properties of SFRC can still be better maintained owing to the inherently high melting temperature and bridging crack effect. Beyond $800^{\circ} \mathrm{C}$, the effect of steel fibers is weakened gradually owing to oxidation and corrosion. In addition, the residual mechanical properties of SFRC are affected by the volume content, physical parameters (aspect ratio and geometric type) of steel fibers, and the temperature history of the sample (heating rate and cooling system).

\section{Explosive Spalling Behavior}

Explosive spalling is a result of the combination of hydraulic, thermal, and mechanical degradation processes inside concrete [82]. When concrete is subjected to fires or high temperatures, the mechanical properties of concrete will be deteriorated significantly, resulting in the rapid deterioration of the bearing capacity of concrete components, which ultimately endangers the safety of concrete structures [15]. It has been well established that the explosive spalling behavior of concrete at high temperatures are due to two main reasons.

One is the accumulation of pore pressure in concrete because of the vaporization of the water inside concrete [13]. Concrete contains free water, chemically bound water in calcium hydroxide $(\mathrm{CH})$ and interlayer water in C-S-H. Initially, the evaporation of free water began at approximately $100{ }^{\circ} \mathrm{C}$, and the pore pressure of the matrix began to increase. When the temperature increased from 300 to $400{ }^{\circ} \mathrm{C}$, the interlayer and chemical bound water of the C-S-H gel began to dehydrate. The calcium hydroxide began to dehydrate between 400 and $500^{\circ} \mathrm{C}$, causing the concrete to begin shrinking and the concrete's strength to reduce significantly. Ultimately, the C-S-H gel would be decomposed entirely at a temperature of approximately $900{ }^{\circ} \mathrm{C}$ [83-91]. As the temperature increases, free water and chemical water in the pore structure of concrete evaporate, a portion of water evacuate to the heated concrete surface, and a large amount of water is vaporized and then migrated to the center of the concrete, where the vapor gathers and begins to condense because of the lower temperature of the inner part of the concrete. After a certain time period, a saturated layer begins to be formed inside the concrete, which prevents the vapor from moving toward the inner concrete. Instead, the vapor moves towards the surface of the concrete on a large scale to enter the atmosphere. The pore pressure in the porous network increases gradually, and the explosive spalling of concrete occurs when the tensile stress of the concrete fails to withstand the pore pressure [17,89]. Kalifa et al. [17] have confirmed the existence of a quasi-saturated layer precedes the drying front by measuring temperature field and the pore pressure of concrete. In addition, when the concrete is exposed to high temperatures, concrete with the lower permeability produces a saturated layer faster, the saturated layer closer to the heated surface, as well as the pore pressure and pressure gradient are higher. The entire process of concrete explosive spalling by pore vapor pressure is shown in Figure 10. The second reason is the cracking of concrete caused by thermal stresses arising from temperature gradients $[13,26]$. Under high temperatures or fires, the heating surface and the interior of concrete will form a thermal gradient, which is often referred to as "thermal shock". When the surface temperature of concrete increases rapidly, concrete shrinkage occurs, and the compression stress generated is parallel to the surface of the heated concrete. In addition, tensile stress is generated in the concrete perpendicular to the surface of the heated concrete. The explosive spalling of concrete occurs once the compressive stress exceeds the tensile stress $[92,93]$. The mechanism of the thermal stress explosive spalling of concrete is shown in Figure 11. Furthermore, owing to the different behaviors of concrete components at elevated temperatures, the heterogeneity of concrete components will cause severe thermal cracking at the interface [94,95]. 


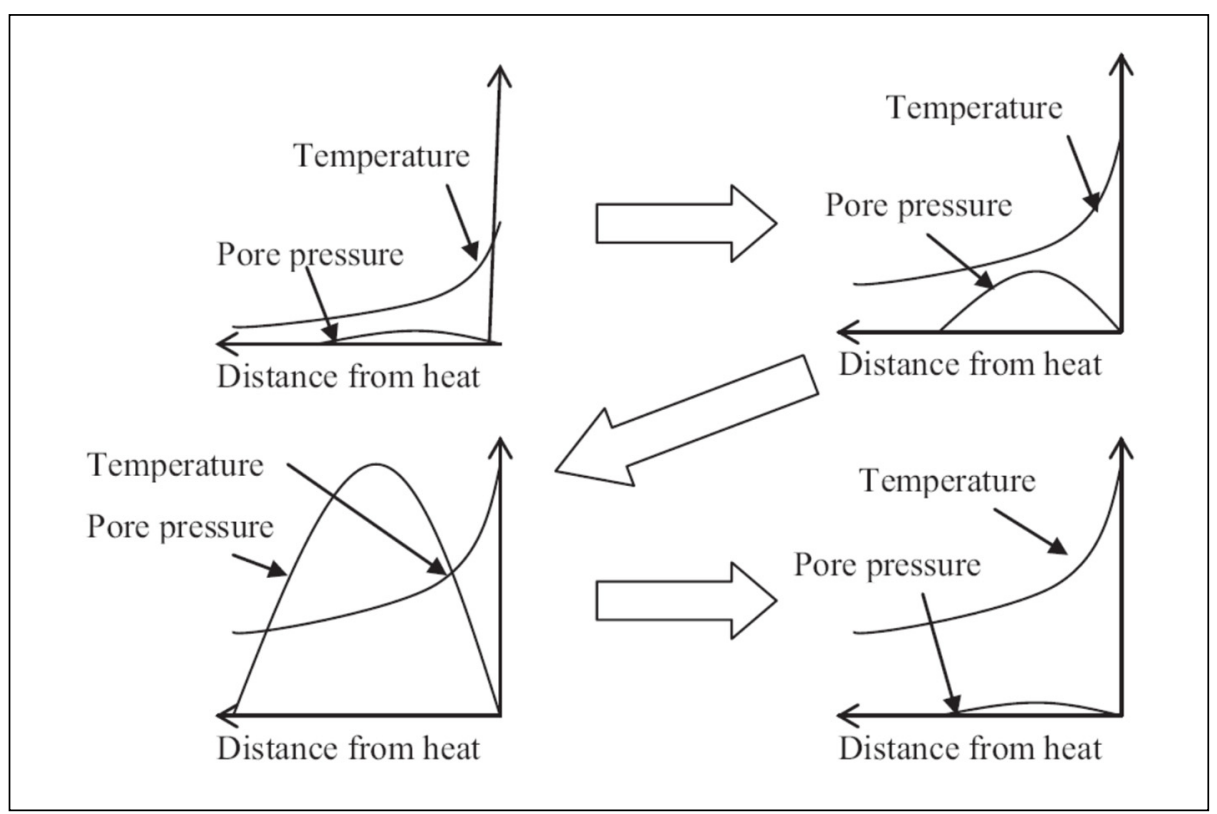

Figure 10. Process of pore pressure explosion spalling of concrete [14].

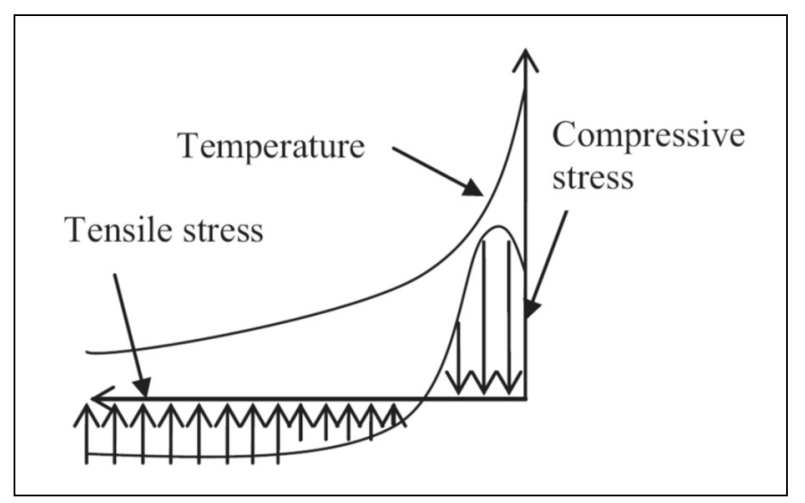

Figure 11. Mechanism of thermal stress explosion spalling of concrete [14].

It is indefinite whether steel fibers would affect the explosive spalling resistance of concrete under high temperatures or fires. Some studies $[67,96,97]$ have shown that steel fibers did not reduce the explosive spalling tendency of concrete. Hertz [96] concluded from experimental data that the application of steel fibers did not reduce the risk of explosion, and that explosive spalling was most likely to occur on specimens with the largest amount of steel fibers. However, other studies have reported that the addition of steel fibers could mitigate the explosive spalling of concrete at high temperatures. The main reasons are as follows. First, the addition of steel fibers can reduce the pore pressure of concrete at high temperatures. Peng et al. [11] demonstrated that steel fibers could overcome the build-up of steam pressure. The results of Li et al. [47] indicated that the application of steel fibers in heated concrete could result in greater pore pressure resistance. Based on the results of Bangi and Horiguchi $[40,47]$, the application of steel fibers could reduce the pore pressure of high-strength concrete when the specimens were subjected to high temperature. Moreover, the positive effect of steel fibers on reducing the pore pressure in the deep part of the concrete during fast heating was more significant than that of slow heating. Subsequently, steel fibers have a much higher thermal conductivity than coarse aggregates and cement substrates; therefore, heat can be transferred more evenly through SFRC, resulting in reduced cracks caused by the thermal gradients of concrete. In the study performed by Felicetti [98], the thermal diffusion coefficient of SFRC was higher than that of ordinary concrete. According to the findings of Gao et al. [28] and Zheng et al. [27], the addition of steel fibers enabled more heat to flow into the interior of concrete, thereby reducing the heating surface, 
interior of the concrete temperature gradient, and thermal shock. This finding is similar to that by Zhang et al. [99] and Zheng et al. [78]. SFRC demonstrated resistance toward explosive spalling owing to thermal gradient reduction. Furthermore, the application of steel fiber can improve the tensile properties of concrete. As described in Section 2.3, the tensile strength of concrete can resist the internal vapor pressure and thermal shock generated by high temperatures, thereby protecting concrete from explosive spalling. Furthermore, steel fibers that are randomly distributed in the matrix can reduce the displacement of the crack tip opening, delay the formation of cracks, and limit the propagation of cracks. This will reduce the probability of explosive spalling as well [27].

Explosive spalling behavior of concrete at high temperature is mainly caused by the accumulation of pore pressure and thermal stress caused by temperature gradient. The application of steel fibers may reduce the risk of explosion by improving the thermal conductivity, tensile properties of concrete and reducing the pore pressure of concrete at high temperatures.

\section{Microstructure of SFRC Exposed to High Temperature}

It has been well established that high temperatures will severely damage the chemical composition and microstructure of concrete but adding steel fibers can improve the microstructure of concrete to some extent. Through SEM observations in Figure 12, Huang et al. [100] reported that the diameter of steel fiber changes and the oxygen content in steel fibers increases with an increase in temperature. This may be due to the small pore near the steel fiber preventing the evaporation of water, and a large amount of water vapor accumulated in the matrix, which caused the steel to rust and oxidation products to deposit on the fiber surface. Kalifa et al. [18] showed that the density of microcracks in the ordinary concrete is much less than that in fiber-reinforced concrete at $400{ }^{\circ} \mathrm{C}$. The microcracks in fiber-reinforced concrete are mainly formed between and around the sand and aggregate skeleton and have a thickness of approximately $1 \mathrm{~mm}$, while the microcracks in ordinary concrete usually occur between large aggregates, with a thickness of about $10 \mathrm{~mm}$. Lau and Anson [33] showed that the porosity of concrete increased with the maximum heating temperature, but the porosity of SFRC was lower and the average pore diameter was smaller than that of concrete without fiber.

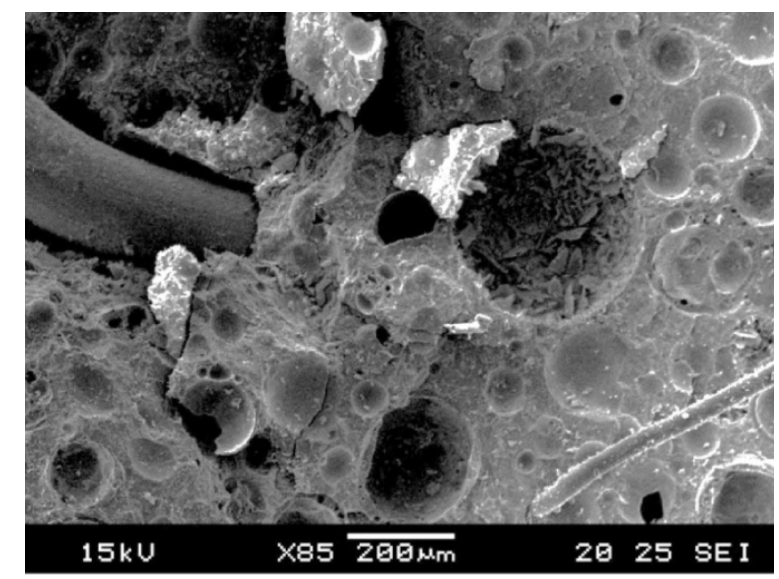

(a) Exposure to $200^{\circ} \mathrm{C}$.

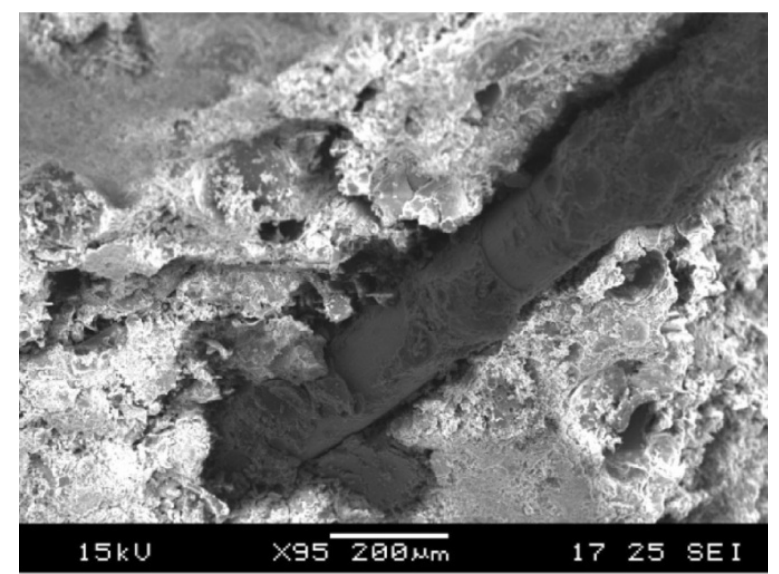

(b) Exposure to $400^{\circ} \mathrm{C}$.

Figure 12. Morphologies of fibers in SFRC exposed to different high temperatures of $200^{\circ} \mathrm{C}(\mathbf{a})$ and $400{ }^{\circ} \mathrm{C}$ (b) [100].

Ahmad et al. [101] investigated the microstructure of the matrix-fiber interface of steel-fiber-reinforced high-performance concrete exposed to high temperatures. As is shown in Figure 13, their results indicated that the matrix-fiber bond strength degraded gradually with increasing exposure time. Moreover, after a period of high-temperature exposure of SFRC, the matrix-fiber bond ruptured progressively and hence thus gradually reduced the activation efficiency 
of steel fiber, which may be due to the contraction arising from the discharge of capillary water and the long-term decomposition of some hydrates at high temperatures. However, it can only reduce the contribution of steel fiber to the high-temperature performance of concrete, rather than eliminate the effect. A few studies $[11,13,41]$ have concluded that steel fiber improved the microstructure of RPC after an elevated temperature. In addition, the investigation of Chen et al. [13,42] indicated that steel fibers positively affected the microstructure of RAC after a high-temperature exposure.

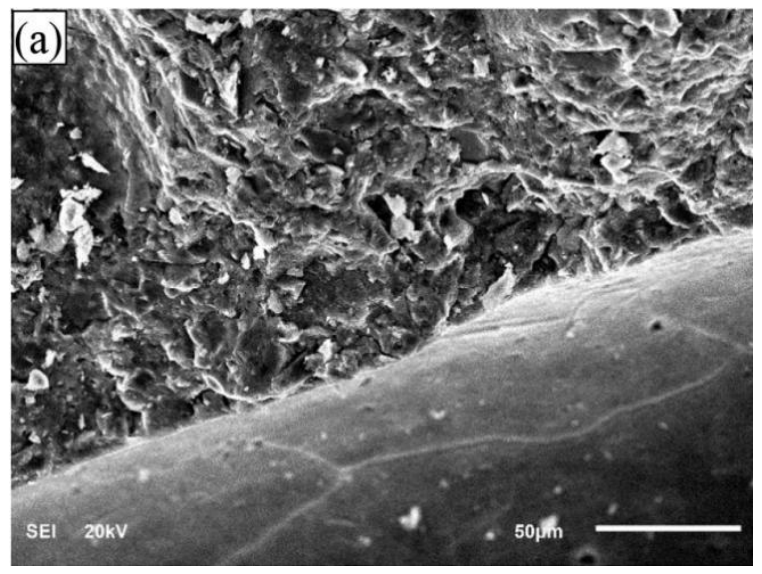

(a) 0 min (unexposed).

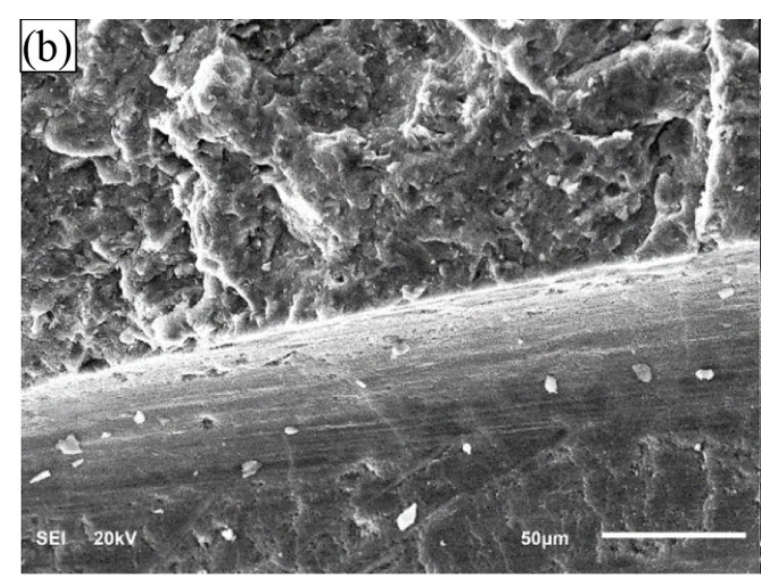

(b) $60 \mathrm{~min}$.

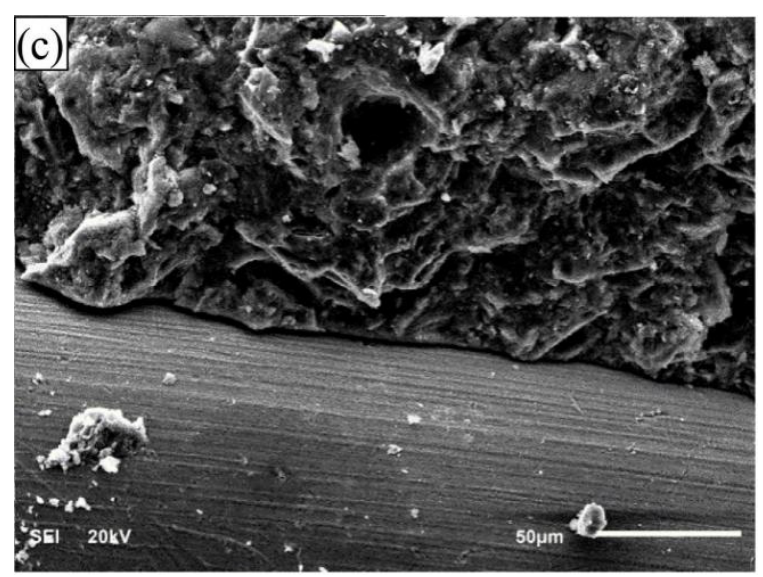

(c) $300 \mathrm{~min}$.

Figure 13. SEM micrograph of CRFC (Steel Fiber Reinforced Concrete) after 0 min (a), $60 \mathrm{~min}(\mathbf{b})$, and $300 \mathrm{~min}(\mathbf{c})$ of a high temperature of $300{ }^{\circ} \mathrm{C}$ [101].

In this section, the effect of steel fibers on the microstructure of heated concrete was described. Compared with the ordinary concrete, SFRC had lower porosity and better microstructure. However, as the exposure time increased and the exposure temperature increased, the steel fibers began to rust and oxidized gradually, reducing their activation efficiency, and eventually leading to a decrease in the contribution to the high temperature performance of the concrete.

\section{Conclusions and Perspectives}

\subsection{Conclusions}

The effect of steel fibers on the mechanical properties, explosive spalling behavior, and microstructure of concrete subjected to high temperatures was reviewed based on the findings of previous studies. The residual compressive strength, flexural properties, tensile strength, elastic 
properties, fracture properties, explosive spalling, and microstructure of SFRC were discussed. The following main conclusions were obtained based on the review:

1. The residual compressive strength of concrete exposed to high temperatures improved significantly by the addition of steel fibers owing to the bridging crack effect and inherently high melting temperature. The residual compressive strength of SFRC was affected by the volume content of steel fibers and the temperature history of the sample, including the heating rate and cooling regime. Most studies have shown that the most significant effect was exerted when the amount of steel fiber was $1 \%$.

2. Steel fibers significantly improved the residual flexural strength of concrete when the exposure temperature was less than $800^{\circ} \mathrm{C}$. Beyond $800^{\circ} \mathrm{C}$, the steel fiber lost its effect gradually owing to oxidation and corrosion. Compared with hybrid steel and polypropylene FRC and single polypropylene FRC, the residual flexural strength of single steel FRC was the highest.

3. The tensile strength of concrete was closely related to its explosive spalling behavior at elevated temperatures. SFRC maintained its good tensile properties at high temperatures. With the increase in steel fiber dosage, the residual tensile strength of SFRC improved significantly. Compared with type, the aspect ratio and volume fraction of steel fiber exerted greater effects on the residual tensile strength.

4. High temperatures exerted the most significant effect on the elastic modulus of concrete. The elastic modulus of SFRC decreased approximately linearly. In addition, steel fibers could enhance the residual elastic properties of RAC.

5. With the increase in exposure temperature (below $400{ }^{\circ} \mathrm{C}$ ), the residual fracture energy of concrete increased gradually. The presence of steel fiber further increased the residual fracture energy and significantly improved the fracture toughness of concrete after elevated temperature exposure. In addition, the enhancement of unstable fracture toughness was approximately twice that of initiation fracture toughness.

6. With the increase in temperature, both the pre-peak and post-peak stages of the stress-strain curve of SFRC became gentler gradually, the peak stress decreased gradually, and the strain at the peak stress increased gradually. Additionally, the presence of steel fibers improved the toughness of heated concrete.

7. Water vapor pressure and thermal stress caused by the temperature gradient inside the concrete at high temperatures were the main causes of explosive spalling. Most studies have reported that the addition of steel fiber reduced the risk of concrete explosive spalling. The presence of steel fiber could decelerate the accumulation of steam pressure inside concrete, reduce the temperature gradient, bridge the microcracks inside concrete, and improve the tensile strength of concrete.

\subsection{Perspectives}

Fire is one of the most harmful situations for various buildings, and the strength of concrete can be seriously compromised when exposed to fire. Researchers often rely on residual mechanical property analyses to assess fire damages to concrete structures; therefore, the topic thereof has been studied extensively. This review focused on the residual mechanical strength of SFRC after elevated temperature exposure, summarized the latest knowledge on this topic, and analyzed the effect of steel fibers on the residual properties of concrete and the action mechanism. However, the behavior of SFRC after elevated temperature exposure depends on many factors, such as the heating rate, duration of exposure, and cooling regime. The lack of standard procedures for heating and cooling concrete samples in various studies and the selection of different heating rates and duration of exposure in various studies renders it difficult to accurately compare test data. Meanwhile, a constant heating rate is not a good representation of structural fire, because the heating rate is variable during fire [102]. Although natural cooling has been used in most studies, rapid cooling has been used in limited studies to simulate firefighting processes. Rapid cooling can cause thermal shock to the heated 
concrete, resulting in a greater damage to the microstructure $[54,102,103]$. This suggests that the residual mechanical properties measured by natural cooling rather than rapid cooling may have been overestimated in most previous studies. Therefore, more experimental data under the condition of rapid cooling must be obtained for the comprehensive evaluation of the residual mechanical properties of SFRC. To fully understand the properties of structures made of SFRC during fire, research on fire resistance of SFRC not only requires residual tests, but also hot tests are essential. The thermal property of concrete is an important component of fire safety design, but research results regarding hot tests on SFRC are still limited hitherto. Therefore, further research is necessitated. In addition, modeling is an effective and useful tool to quantitatively understand the key processes of SFRC changes at high temperatures, which can be used to represent and simulate the field behavior of SFRC more accurately. Therefore, there should be focus on modeling as well [104]. In summary, although the performance of SFRC exposed to high temperature has been investigated extensively, fires are complex and volatile; therefore, more tests and research are warranted to realize the full potential of SFRC as a fire-resistant building material.

Author Contributions: Conceptualization, P.Z., L.K. and J.W.; formal analysis, P.Z., L.K., J.W., J.G.; resources, J.G.; writing—original draft preparation, P.Z., L.K., and J.W.; writing—review and editing, L.K. J.G. S.H. and Y.L.; supervision, S.H.; project administration, J.W.; funding acquisition, P.Z. All authors have read and agreed to the published version of the manuscript.

Funding: This research was funded by National Natural Science Foundation of China (Grant No. 51678534, 51979251), the CRSRI Open Research Program of China (Grant No. CKWV2018477/KY), Open Projects Funds of Dike Safety and Disaster Prevention Engineering Technology Research Center of Chinese Ministry of Water Resources of China (Grant no. 2018006) and Program for Innovative Research Team (in Science and Technology) in University of Henan Province of China (Grant No. 20IRTSTHN009).

Conflicts of Interest: The authors declare no conflict of interest.

\section{References}

1. Rashiddadash, P.; Ramezanianpour, A.A.; Mahdikhani, M. Experimental investigation on flexural toughness of hybrid fiber reinforced concrete (HFRC) containing metakaolin and pumice. Constr. Build. Mater. 2014, 51, 313-320. [CrossRef]

2. Thokchom, S.; Ghosh, P.; Ghosh, S. Performance of fly ash based geopolymer mortars in sulphate solution. J. Eng. Sci. Technol. Rev. 2010, 3, 36-40. [CrossRef]

3. Luhar, S.; Cheng, T.W.; Nicolaides, D.; Luhar, I.; Panias, D.; Sakkas, K. Valorisation of glass wastes for the development of geopolymer composites-Durability, thermal and microstructural properties: A review. Constr. Build. Mater. 2019, 222, 673-687. [CrossRef]

4. Luhar, S.; Cheng, T.W.; Nicolaides, D.; Luhar, I.; Panias, D.; Sakkas, K. Valorisation of glass waste for development of geopolymer composites-Mechanical properties and rheological characteristics: A review. Constr. Build. Mater. 2019, 220, 547-564. [CrossRef]

5. Noumowe, A.N.; Clastres, P.; Debicki, G.; Costaz, J.L. High performance concrete for severe thermal conditions. In Proceedings of the International Conference on Concrete under Severe Conditions, CONSEC'95, Sapporo, Japan, 2-4 August 1995; E \& FN Spon: London, UK, 1995; pp. 1129-1140.

6. Arioz, O. Effects of elevated temperatures on properties of concrete. Fire Saf. J. 2007, 42, 516-522. [CrossRef]

7. Krishna, D.A.; Priyadarsini, R.S.; Narayanan, S. Effect of elevated temperatures on the mechanical properties of concrete. Procedia Struct. Integr. 2019, 14, 384-394. [CrossRef]

8. Caetano, H.; Ferreira, G.; Rodrigues, J.P.C.; Pimienta, P. Effect of the high temperatures on the microstructure and compressive strength of high strength fibre concretes. Constr. Build. Mater. 2019, 199, 717-736. [CrossRef]

9. Handoo, S.K.; Agarwal, S.; Agarwal, S.K. Physicochemical, mineralogical, and morphological characteristics of concrete exposed to elevated temperatures. Cem. Concr. Res. 2002, 32, 1009-1018. [CrossRef]

10. Li, M.; Qian, C.; Sun, W. Mechanical properties of high-strength concrete after fire. Cem. Concr. Res. 2004, 34, 1001-1005. [CrossRef]

11. Peng, G.F.; Yang, W.W.; Zhao, J.; Liu, Y.F.; Bian, S.H.; Zhao, L.H. Explosive spalling and residual mechanical properties of fiber-toughened high-performance concrete subjected to high temperatures. Cem. Concr. Res. 2006, 36, 723-727. [CrossRef] 
12. Janotka, I.; Bagel, L. Pore structures, permeabilities, and compressive strengths of concrete at temperatures up to $800^{\circ}$ C. Mater. J. 2002, 99, 196-200.

13. Chen, G.M.; Yang, H.; Lin, C.J.; Chen, J.F.; He, Y.H.; Zhang, H.Z. Fracture behaviour of steel fibre reinforced recycled aggregate concrete after exposure to elevated temperatures. Constr. Build. Mater. 2016, 128, 272-286. [CrossRef]

14. Ma, Q.; Guo, R.; Zhao, Z.; Lin, Z.; He, K. Mechanical properties of concrete at high temperature-A review. Constr. Build. Mater. 2015, 93, 371-383. [CrossRef]

15. Fu, Y.F.; Wong, Y.L.; Poon, C.S.; Tang, C.A. Literature review of study on mechanism of explosive spalling in concrete at elevated temperatures. J. Build. Mater. 2006, 9, 323-329.

16. Bažant, Z.P.; Kaplan, M.F.; Bazant, Z.P. Concrete at High Temperatures: Material Properties and Mathematical Models; Longman-Addison-Wesley: London, UK, 1996.

17. Kalifa, P.; Menneteau, F.D.; Quenard, D. Spalling and pore pressure in HPC at high temperatures. Cem. Concr. Res. 2000, 30, 1915-1927. [CrossRef]

18. Kalifa, P.; Chene, G.; Galle, C. High-temperature behaviour of HPC with polypropylene fibres: From spalling to microstructure. Cem. Concr. Res. 2001, 31, 1487-1499. [CrossRef]

19. Romualdi, J.P.; Ramey, M.; Sanday, S.C. Prevention and control of cracking by use of short random fibers. Spec. Publ. 1968, 20, 179-204.

20. Ding, Y.; Zhang, F.; Torgal, F.; Zhang, Y. Shear behaviour of steel fibre reinforced self-consolidating concrete beams based on the modified compression field theory. Compos. Struct. 2012, 94, 2440-2449. [CrossRef]

21. Eik, M.; Puttonen, J.; Herrmann, H. An orthotropic material model for steel fibre reinforced concrete based on the orientation distribution of fibres. Compos. Struct. 2015, 121, 324-336. [CrossRef]

22. Abdallah, S.; Fan, M.; Zhou, X.; Le Geyt, S. Anchorage effects of various steel fibre architectures for concrete reinforcement. Int. J. Concr. Struct. Mater. 2016, 10, 325-335. [CrossRef]

23. Laranjeira, F.; Molins, C.; Aguado, A. Predicting the pullout response of inclined hooked steel fibers. Cem. Concr. Res. 2010, 40, 1471-1487. [CrossRef]

24. Zīle, E.; Zìle, O. Effect of the fiber geometry on the pullout response of mechanically deformed steel fibers. Cem. Concr. Res. 2013, 44, 18-24. [CrossRef]

25. Varona, F.B.; Baeza, F.J.; Bru, D.; Ivorra, S. Influence of high temperature on the mechanical properties of hybrid fibre reinforced normal and high strength concrete. Constr. Build. Mater. 2018, 159, 73-82. [CrossRef]

26. Li, Y.; Pimienta, P.; Pinoteau, N.; Tan, K.H. Effect of aggregate size and inclusion of polypropylene and steel fibers on explosive spalling and pore pressure in ultra-high-performance concrete (UHPC) at elevated temperature. Cem. Concr. Compos. 2019, 99, 62-71. [CrossRef]

27. Zheng, W.; Luo, B.; Wang, Y. Compressive and tensile properties of reactive powder concrete with steel fibres at elevated temperatures. Constr. Build. Mater. 2013, 41, 844-851. [CrossRef]

28. Gao, D.; Yan, D.; Li, X. Splitting strength of GGBFS concrete incorporating with steel fiber and polypropylene fiber after exposure to elevated temperatures. Fire Saf. J. 2012, 54, 67-73. [CrossRef]

29. Poon, C.S.; Shui, Z.H.; Lam, L.; Fok, H.; Kou, S.C. Influence of moisture states of natural and recycled aggregates on the slump and compressive strength of concrete. Cem. Concr. Res. 2004, 34, 31-36. [CrossRef]

30. Poon, C.S.; Shui, Z.H.; Lam, L. Compressive behavior of fiber reinforced high-performance concrete subjected to elevated temperatures. Cem. Concr. Res. 2004, 34, 2215-2222. [CrossRef]

31. Purkiss, J.A. Steel fibre reinforced concrete at elevated temperatures. Int. J. Cem. Compos. Lightweight Concr. 1984, 6, 179-184. [CrossRef]

32. Faiyadh, F.I.; Al-Ausi, M.A. Effect of elevated temperature on splitting tensile strength of fibre concrete. Int. J. Cem. Compos. Lightweight Concr. 1989, 11, 175-178. [CrossRef]

33. Lau, A.; Anson, M. Effect of high temperatures on high performance steel fibre reinforced concrete. Cem. Concr. Res. 2006, 36, 1698-1707. [CrossRef]

34. Rilem, T.C. Test methods for mechanical properties of concrete at high temperatures, Recommendations, Part 3: Compressive strength for service and accident conditions. Mater. Struct. 1995, 28, 410-414.

35. Rilem, T.C. Test methods for mechanical properties of concrete at high temperatures recommendations-Part 4: Tensile strength for service and accident conditions. Mater. Struct. 2000, 33, 219-223.

36. Ismail, R.; Zakwan, F.A.A.; Petrus, C.; Marzuki, N.A.; Hashim, N.H.; Mustafa, M.F. Compressive behavior of steel fiber reinforced concrete after exposed to high temperatures. In CIEC 2013; Springer: Singapore, 2014; pp. 731-740. 
37. Xie, J.; Zhang, Z.; Lu, Z.; Sun, M. Coupling effects of silica fume and steel-fiber on the compressive behaviour of recycled aggregate concrete after exposure to elevated temperature. Constr. Build. Mater. 2018, 184, 752-764. [CrossRef]

38. Zhao, J.; Gao, D.Y.; Wang, B. The experimental study on mechanical property of steel fiber reinforced high strength concrete after high temperature. Concrete 2006, 28, 4-6.

39. Chen, H.G.; Liu, F.Y.; Sun, B.; Wang, M.; Cheng, P.J. Impact of steel fibre dosage on mechanical properties of concrete under high temperature. J. Chongqing Jiaotong Univ. 2010, 29, 552-554.

40. Düğenci, O.; Haktanir, T.; Altun, F. Experimental research for the effect of high temperature on the mechanical properties of steel fiber-reinforced concrete. Constr. Build. Mater. 2015, 75, 82-88. [CrossRef]

41. Shaikh, F.U.A.; Hosan, A. Mechanical properties of steel fibre reinforced geopolymer concretes at elevated temperatures. Constr. Build. Mater. 2016, 114, 15-28. [CrossRef]

42. Chen, G.M.; He, Y.H.; Yang, H.; Chen, J.F.; Guo, Y.C. Compressive behavior of steel fiber reinforced recycled aggregate concrete after exposure to elevated temperatures. Constr. Build. Mater. 2014, 71, 1-15. [CrossRef]

43. Tai, Y.S.; Pan, H.H.; Kung, Y.N. Mechanical properties of steel fiber reinforced reactive powder concrete following exposure to high temperature reaching $800^{\circ} \mathrm{C}$. Nucl. Eng. Des. 2011, 241, 2416-2424. [CrossRef]

44. Li, L.; Zhang, R.; Jin, L.; Du, X.; Wu, J.; Duan, W. Experimental study on dynamic compressive behavior of steel fiber reinforced concrete at elevated temperatures. Constr. Build. Mater. 2019, 210, 673-684. [CrossRef]

45. Mehta, P.K. Concrete: Structure, Properties and Materials; Prentice-Hall Inc.: Englewood Cliffs, NJ, USA, 1986.

46. Khoury, G.A. Effect of fire on concrete and concrete structures. Prog. Struct. Eng. Mater. 2000, 2, 429-447. [CrossRef]

47. Bangi, M.R.; Horiguchi, T. Effect of fibre type and geometry on maximum pore pressures in fibre-reinforced high strength concrete at elevated temperatures. Cem. Concr. Res. 2012, 42, 459-466. [CrossRef]

48. Zheng, W.; Li, H.; Wang, Y. Compressive behaviour of hybrid fiber-reinforced reactive powder concrete after high temperature. Mater. Des. 2012, 41, 403-409. [CrossRef]

49. Scheinherrová, L.; Vejmelková, E.; Keppert, M.; Bezdička, P.; Doleželová, M.; Krejsová, J.; Grzeszczyk, S.; Matuszek-Chmurowska, A.; Černý, R. Effect of Cu-Zn coated steel fibers on high temperature resistance of reactive powder concrete. Cem. Concr. Res. 2019, 117, 45-57. [CrossRef]

50. Bangi, M.R.; Horiguchi, T. Pore pressure development in hybrid fibre-reinforced high strength concrete at elevated temperatures. Cem. Concr. Res. 2011, 41, 1150-1156. [CrossRef]

51. Luo, X.; Sun, W.; Chan, S.Y.N. Effect of heating and cooling regimes on residual strength and microstructure of normal strength and high-performance concrete. Cem. Concr. Res. 2000, 30, 379-383. [CrossRef]

52. Ishihara, S.; Goshima, T.; Nomura, K.; Yoshimoto, T. Crack propagation behavior of cermets and cemented carbides under repeated thermal shocks by the improved quench test. J. Mater. Sci. 1999, 34, 629-636. [CrossRef]

53. Nassif, A.Y. Postfiring stress-strain hysteresis of concrete subjected to various heating and cooling regimes. Fire Mater. 2002, 26, 103-109. [CrossRef]

54. Totten, G.E. Steel Heat Treatment Handbook; CRC Press: Boca Raton, FL, USA, 2006; Volume 2.

55. Li, Y.; Yang, E.H.; Tan, K.H. Effects of heating followed by water quenching on strength and microstructure of ultra-high performance concrete. Constr. Build. Mater. 2019, 207, 403-411. [CrossRef]

56. Jameran, A.; Ibrahim, I.S.; Yazan, S.H.S.; Rahim, S.N.A. Mechanical properties of steel-polypropylene fibre reinforced concrete under elevated temperature. Procedia Eng. 2015, 125, 818-824. [CrossRef]

57. Choumanidis, D.; Badogiannis, E.; Nomikos, P.; Sofianos, A. The effect of different fibres on the flexural behaviour of concrete exposed to normal and elevated temperatures. Constr. Build. Mater. 2016, 129, $266-277$. [CrossRef]

58. Yermak, N.; Pliya, P.; Beaucour, A.L.; Simon, A.; Noumowé, A. Influence of steel and/or polypropylene fibres on the behaviour of concrete at high temperature: Spalling, transfer and mechanical properties. Constr. Build. Mater. 2017, 132, 240-250. [CrossRef]

59. Ezziane, M.; Molez, L.; Jauberthie, R.; Rangeard, D. Heat exposure tests on various types of fibre mortar. Eur. J. Environ. Civ. Eng. 2011, 15, 715-726. [CrossRef]

60. Pliya, P.; Beaucour, A.L.; Noumowé, A. Contribution of cocktail of polypropylene and steel fibres in improving the behaviour of high strength concrete subjected to high temperature. Constr. Build. Mater. 2011, 25, 1926-1934. [CrossRef] 
61. British Standard Institute. Eurocode 2: Design of Concrete Structure-Part 1. 2: General Rules-Structural Fire Design; BS EN. 1992-1-2:2004; British Standard Institute: London, UK, 2004.

62. Xiao, J.; Xie, Q.; Xie, W. Study on high-performance concrete at high temperatures in China (2004-2016)-An updated overview. Fire Saf. J. 2018, 95, 11-24. [CrossRef]

63. Kim, J.; Lee, G.P. Evaluation of mechanical properties of steel-fibre-reinforced concrete exposed to high temperatures by double-punch test. Constr. Build. Mater. 2015, 79, 182-191. [CrossRef]

64. Mindess, S.; Young, J.F.; Darwin, D. Concrete, Pearson Education; Pearson Education: Upper SaddleRiver, NJ, USA, 2003.

65. Khaliq, W.; Kodur, V. High temperature mechanical properties of high-strength fly ash concrete with and without fibers. ACI Mater. J. 2012, 109, 665-674.

66. Suhaendi, S.L.; Horiguchi, T. Effect of short fibers on residual permeability and mechanical properties of hybrid fibre reinforced high strength concrete after heat exposition. Cem. Concr. Res. 2006, 36, 1672-1678. [CrossRef]

67. Aydın, S.; Yazıcı, H.; Baradan, B. High temperature resistance of normal strength and autoclaved high strength mortars incorporated polypropylene and steel fibers. Constr. Build. Mater. 2008, 22, 504-512. [CrossRef]

68. Gao, C.; Yang, D.; Yu, J.; Wang, L.; Li, P. Mechanical properties of fiber reinforcedconcrete after high temperature. Concrete 2013, 35, 33-36.

69. Chen, B.; Liu, J. Residual strength of hybrid-fiber-reinforced high-strength concrete after exposure to high temperatures. Cem. Concr. Res. 2004, 34, 1065-1069. [CrossRef]

70. Guo, Y.C.; Zhang, J.H.; Chen, G.M.; Xie, Z.H. Compressive behaviour of concrete structures incorporating recycled concrete aggregates, rubber crumb and reinforced with steel fibre, subjected to elevated temperatures. J. Clean. Prod. 2014, 72, 193-203. [CrossRef]

71. Khaliq, W.; Kodur, V. Thermal and mechanical properties of fiber reinforced high performance self-consolidating concrete at elevated temperatures. Cem. Concr. Res. 2011, 41, 1112-1122. [CrossRef]

72. Guo, Y.C.; Zhang, J.H.; Chen, G.; Chen, G.M.; Xie, Z.H. Fracture behaviors of a new steel fiber reinforced recycled aggregate concrete with crumb rubber. Constr. Build. Mater. 2014, 53, 32-39. [CrossRef]

73. Menou, A.; Mounajed, G.; Boussa, H.; Pineaud, A.; Carre, H. Residual fracture energy of cement paste, mortar and concrete subject to high temperature. Theor. Appl. Fract. Mech. 2006, 45, 64-71. [CrossRef]

74. Nielsen, C.V.; Biéanić, N. Residual fracture energy of high-performance and normal concrete subject to high temperatures. Mater. Struct. 2003, 36, 515. [CrossRef]

75. Watanabe, K.; Bangi, M.R.; Horiguchi, T. The effect of testing conditions (hot and residual) on fracture toughness of fiber reinforced high-strength concrete subjected to high temperatures. Cem. Concr. Res. 2013, 51, 6-13. [CrossRef]

76. Ding, Y.; Azevedo, C.; Aguiar, J.B.; Jalali, S. Study on residual behaviour and flexural toughness of fibre cocktail reinforced self compacting high performance concrete after exposure to high temperature. Constr. Build. Mater. 2012, 26, 21-31. [CrossRef]

77. Ríos, J.D.; Cifuentes, H.; Leiva, C.; Seitl, S. Analysis of the mechanical and fracture behavior of heated ultra-high-performance fiber-reinforced concrete by X-ray computed tomography. Cem. Concr. Res. 2019, 119, 77-88. [CrossRef]

78. Zheng, W.; Li, H.; Wang, Y. Compressive stress-strain relationship of steel fiber-reinforced reactive powder concrete after exposure to elevated temperatures. Constr. Build. Mater. 2012, 35, 931-940. [CrossRef]

79. Colombo, M.; Di Prisco, M.; Felicetti, R. Mechanical properties of steel fibre reinforced concrete exposed at high temperatures. Mater. Struct. 2010, 43, 475-491. [CrossRef]

80. Taerwe, L.R. Influence of steel fibers on strain-softening of high-strength concrete. Mater. J. 1993, 89, 54-60.

81. Nataraja, M.C.; Dhang, N.; Gupta, A.P. Stress-strain curves for steel-fiber reinforced concrete under compression. Cem. Concr. Compos. 1999, 21, 383-390. [CrossRef]

82. Gawin, D.; Alonso, C.; Andrade, C.; Majorana, C.E.; Pesavento, F. Effect of damage on permeability and hygro-thermal behaviour of HPCs at elevated temperatures: Part 1. Experimental results. Comput. Concr. 2005, 2, 189-202. [CrossRef]

83. Chan, Y.N.; Peng, G.F.; Anson, M. Residual strength and pore structure of high-strength concrete and normal strength concrete after exposure to high temperatures. Cem. Concr. Compos. 1999, 21, 23-27. [CrossRef] 
84. Alarcon-Ruiz, L.; Platret, G.; Massieu, E.; Ehrlacher, A. The use of thermal analysis in assessing the effect of temperature on a cement paste. Cem. Concr. Res. 2005, 35, 609-613. [CrossRef]

85. Alonso, C.; Fernandez, L. Dehydration and rehydration processes of cement paste exposed to high temperature environments. J. Mater. Sci. 2004, 39, 3015-3024. [CrossRef]

86. Castellote, M.; Alonso, C.; Andrade, C.; Turrillas, X.; Campo, J. Composition and microstructural changes of cement pastes upon heating, as studied by neutron diffraction. Cem. Concr. Res. 2004, 34, 1633-1644. [CrossRef]

87. Hager, I. Behaviour of cement concrete at high temperature. Bull. Pol. Acad. Sci. Tech. Sci. 2013, 61, 145-154. [CrossRef]

88. Lim, S. Effects of Elevated Temperature Exposure on Cement-Based Composite Materials. Ph.D. Thesis, University of Illinois at Urbana-Champaign, Champaign, IL, USA, 2015.

89. Consolazio, G.R.; McVay, M.C.; Rish, J.W., III. Measurement and prediction of pore pressures in saturated cement mortar subjected to radiant heating. Mater. J. 1998, 95, 525-536.

90. Henry, M.; Darma, I.S.; Sugiyama, T. Analysis of the effect of heating and re-curing on the microstructure of high-strength concrete using X-ray CT. Constr. Build. Mater. 2014, 67, 37-46. [CrossRef]

91. Fletcher, I.A.; Welch, S.; Torero, J.L.; Carvel, R.O.; Usmani, A. The behaviour ofconcrete structures in fire. Therm. Sci. 2007, 11, 1-16. [CrossRef]

92. Ozawa, M.; Uchida, S.; Kamada, T.; Morimoto, H. Study of mechanisms of explosive spalling in high-strength concrete at high temperatures using acoustic emission. Constr. Build. Mater. 2012, 37, 621-628. [CrossRef]

93. Debicki, G.; Haniche, R.; Delhomme, F. An experimental method for assessing the spalling sensitivity of concrete mixture submitted to high temperature. Cem. Concr. Compos. 2012, 34, 958-963. [CrossRef]

94. Naus, D. The Effect of Elevated Temperature on Concrete Materials and Structures: A Literature Review; Division of Engineering Technology, Office of Nuclear Regulatory Research, US Nuclear Regulatory Commission: Rockville, MD, USA, 2006.

95. Varona, F.B.; Baeza, F.J.; Bru, D.; Ivorra, S. Evolution of the bond strength between reinforcing steel and fibre reinforced concrete after high temperature exposure. Constr. Build. Mater. 2018, 176, 359-370. [CrossRef]

96. Hertz, K.D. Danish investigations on silica fume concretes at elevated temperatures. Mater. J. 1992, 89, 345-347.

97. Sideris, K.K.; Manita, P.; Chaniotakis, E. Performance of thermally damaged fibre reinforced concretes. Constr. Build. Mater. 2009, 23, 1232-1239. [CrossRef]

98. Felicetti, R. Assessment of the equivalent thermal diffusivity for fire analysis of concrete structures. In Proceedings of the Fib Task Group 4.3 Workshop Fire Design of Concrete Structures, Coimbra, Portugal, 8-9 November 2007.

99. Zhang, D.; Ju, L. Effects of hybrid fiber on HPC properties under hightemperature. Ind. Constr. 2005, 35, 8-14.

100. Huang, Z.; Padmaja, K.; Li, S.; Liew, J.R. Mechanical properties and microstructure of ultra-lightweight cement composites with fly ash cenospheres after exposure to high temperatures. Constr. Build. Mater. 2018, 164, 760-774. [CrossRef]

101. Ahmad, S.; Rasul, M.; Adekunle, S.K.; Al-Dulaijan, S.U.; Maslehuddin, M.; Ali, S.I. Mechanical properties of steel fiber-reinforced UHPC mixtures exposed to elevated temperature: Effects of exposure duration and fiber content. Compos. Part B Eng. 2019, 168, 291-301. [CrossRef]

102. Mohamedbhai, G.T.G. Effect of exposure time and rates of heating and cooling on residual strength of heated concrete. Mag. Concr. Res. 1986, 38, 151-158. [CrossRef]

103. Peng, G.F.; Bian, S.H.; Guo, Z.Q.; Zhao, J.; Peng, X.L.; Jiang, Y.C. Effect of thermal shock due to rapid cooling on residual mechanical properties of fiber concrete exposed to high temperatures. Constr. Build. Mater. 2008, 22, 948-955. [CrossRef]

104. Khoury, G.A.; Majorana, C.E.; Pesavento, F.; Schrefler, B.A. Modelling of heated concrete. Mag. Concr. Res. 2002, 54, 77-101. [CrossRef]

(C) 2020 by the authors. Licensee MDPI, Basel, Switzerland. This article is an open access article distributed under the terms and conditions of the Creative Commons Attribution (CC BY) license (http://creativecommons.org/licenses/by/4.0/). 